\title{
Dissociation of Glomerular Hypertrophy, Cell Proliferation, and Glomerulosclerosis in Mouse Strains Heterozygous for a Mutation (Os) which Induces a 50\% Reduction in Nephron Number
}

\author{
Ci-jiang He, ${ }^{\star}$ Ciro Esposito, ${ }^{\star}$ Carrie Phillips, ${ }^{\star}$ Rudolfs K. Zalups, ${ }^{\ddagger}$ David A. Henderson, ${ }^{\S}$ Gary E. Striker, ${ }^{\star}$ \\ and Liliane J. Striker* \\ *Renal Cell Biology Section, Metabolic Diseases Branch, National Institute of Diabetes and Digestive and Kidney Diseases, National \\ Institutes of Health, Bethesda, Maryland 20892; ${ }^{\ddagger}$ Division of Basic Medical Sciences, Mercer University, School of Medicine, Macon, \\ Georgia 31207; and ${ }^{\S}$ Department of Research, College of Osteopathic Medicine, Oklahoma State University, Tulsa, Oklahoma 74107-1898
}

\begin{abstract}
We reported that the Os mutation in ROP mice induced a $50 \%$ reduction in nephron number, glomerular hypertrophy, and severe glomerulosclerosis. We examined two mouse strains with the Os mutation, ROP Os/+ and C57 Os/+ mice, to determine whether the genetic background influenced the development of glomerulosclerosis. Nephron number was decreased by 50\% in both ROP Os/+ and C57 $\mathrm{Os} /+$ mice, and a glomerular volume and labeling index were two- to threefold increased in both. Whereas glomerulosclerosis was severe in ROP Os/+ mice, it was absent or minimal in C57 Os/+ mice. ROP Os/+ glomeruli had twoto threefold more type IV collagen, laminin, and tenascin than $\mathrm{C} 57 \mathrm{Os} /+$ by immunofluorescence microscopy. Glomerular $\alpha 1 \mathrm{IV}$ collagen and tenascin mRNA levels were increased (2.8- and 1.7-fold) in ROP Os/+ and in C57 Os/+ (1.7- and 1.4-fold) mice. Both ROP Os/+ and C57 Os/+ mice had a slight increase (1.5- and 1.7 -fold) in $72-\mathrm{kD}$ collagenase mRNA levels. Whereas laminin B1 mRNA levels were twofold higher in ROP $+I+$ than in $\mathrm{C} 57+I+$ mice, there was no further change in the presence of the Os mutation. Thus, the response to the Os mutation depended on the mouse strain, since severe glomerulosclerosis occurred only in ROP Os/ + mice, even though cell proliferation and glomerular hypertrophy also were present in C57 Os/+ mice. (J. Clin. Invest. 1996. 97:1242-1249.) Key words: nephron number • glomerular hypertrophy • glomerular extracellular matrix mRNAs
\end{abstract}

\section{Introduction}

There is considerable individual variability in the susceptibility to develop glomerular diseases. For example, only a fraction of diabetic patients develop nephropathy regardless of the level of glycemic control (1-3) while the incidence of $\operatorname{IgA}$ nephropathy and its rate of progression vary widely with the ethnic background $(4,5)$. It is also noteworthy that the rate of progression of a given disease varies between individuals $(6,7)$. Although glomerulosclerosis appears to be multifactorial, the

Address correspondence to Liliane J. Striker, NIDDK/MDB/RCBS, Building 10, Room 3N 110, 10 Center Drive MSC 1268, Bethesda, MD 20892-1268. Phone: 301-496-5837; FAX: 301-402-2233.

Received for publication 23 August 1995 and accepted in revised form 8 December 1995.

The Journal of Clinical Investigation

Volume 97, Number 5, March 1996, 1242-1249 nature of a genetic predisposition to glomerular scarring has not been identified.

An insufficient number of nephrons at birth has been implicated in the pathogenesis of glomerulosclerosis in humans (8-10). Multiple factors have been shown to affect the number of glomeruli present at birth including placental weight, birth weight, and exposure to toxins in utero $(11,12)$. An inverse relationship between birth weight and hypertension later in life was found in some patients (13), and this may be causally related to the increased risk of end-stage renal disease in individuals born with an insufficient number of nephrons and in young adults with increased glomerular size (14-17). These data in humans suggest that there is a relationship between nephron reduction at birth and the increased susceptibility to glomerulosclerosis in adult life.

The ROP Os/+ mouse is a mutant strain born with a $50 \%$ reduction in the number of nephrons and oligosyndactyly (18, 19). We reported that they had glomerular hypertrophy and glomerulosclerosis at $3 \mathrm{mo}$, with increased glomerular cell turnover and extracellular matrix synthesis (20). In the current study, we explored the linkage between glomerular hypertrophy, cell proliferation, extracellular matrix turnover, and glomerulosclerosis in two different mouse strains (ROP and C57) carrying the Os mutation. We found that nephron number, as well as glomerular hypertrophy and cell turnover, were identical in C57 Os/+ and ROP Os/+ mice. However, severe mesangial sclerosis and increased type IV collagen transcription and deposition were present in ROP Os/+ mice, but the changes in C57 Os/+ mice were much less marked. These data show that the effects of the Os mutation on nephron number, glomerular cell proliferation, the expression of certain genes important in extracellular matrix turnover, and glomerular size were identical between strains. However, the degree of glomerulosclerosis differed markedly between the two strains and was independent of glomerular cell proliferation and hypertrophy.

\section{Methods}

Experimental design. Female ROP Os/+, ROP +/+, C57 Os/+, and C57 +/+ mice were obtained from Jackson Laboratories (Bar Harbor, ME). Six C57 +/+ and C57 Os/+ mice were killed at 3 mo according to National Institutes of Health approved procedures. An additional group of six ROP Os/+, ROP $+/+$, C57 Os/+, and C57 +/+ mice were killed at $5 \mathrm{mo}$. ROP $+/+$ and $\mathrm{C} 57+/+$ mice served as controls for ROP Os/+ and C57 Os/+ mice. The left kidney was perfused with a buffer solution containing collagenase and RNAse inhibitors for glomerular microdissection as described previously (21). The right kidney was used for microscopic studies. An additional three $\mathrm{C} 57+/+$ and three $\mathrm{C} 57 \mathrm{Os} /+$ mice aged $7.5 \mathrm{mo}$ were used for light microscopy. For study by electron microscopy, five C57 +/+ and five C57 Os/+ 
3-mo-old mice were killed. The kidneys were perfusion fixed by intracardiac gravity at $100 \mathrm{mmHg}$ as follows: a $20 \mathrm{~s}$ prewash with PBS (350 mOsM, pH 7.4) followed by fixative (1\% glutaraldehyde in $0.1 \mathrm{M}$ Sorensen's phosphate buffer, $350 \mathrm{mOsM}$, pH 7.4) for $5 \mathrm{~min}$. We have previously shown that glomerular filtration rate, estimated by creatinine clearance, did not differ between 3-mo-old ROP Os/+ and $+/+$ mice (19). Thus, ROP Os/+ mice had no early renal functional changes secondary to the $50 \%$ reduction in renal mass. The protein/ creatinine ratio was measured in urine samples as reported previously $(19,22)$.

Glomerular number. Glomerular number was determined as described previously in $\mathrm{C} 57+/+$ and $\mathrm{C} 57 \mathrm{Os} /+$ mice at 3 mo of age (22). Briefly, the kidneys were decapsulated, cut into $2 \mathrm{~mm}^{3}$ pieces, and incubated in $5 \mathrm{ml}$ of $6 \mathrm{~N} \mathrm{HCl}$ at $37^{\circ} \mathrm{C}$ for $90 \mathrm{~min}$. The resultant suspension was diluted to $30 \mathrm{ml}$ with distilled $\mathrm{H}_{2} \mathrm{O}$ and allowed to stand at $4^{\circ} \mathrm{C}$ overnight. Glomerular number was determined in triplicate under phase microscopy using a counting chamber.

Light microscopy. Coronal kidney sections were fixed in Carnoy's fixative, embedded in glycol methacrylate, cut at a thickness of $2 \mu \mathrm{m}$, and stained with hematoxylin/eosin or periodic acid-Schiff. The sections were examined without knowledge of the experimental groups. The degree of mesangial sclerosis was assessed using a scale from 0 to $4+(23) .40$ glomeruli per section were examined in six mice from each group, and the mean of scores for individual glomeruli was recorded.

Immunofluorescence microscopy. Fragments were embedded in low-temperature melting paraffin, sectioned at $5 \mu \mathrm{m}$, deparaffinized, and rehydrated (24). After light trypsinization at $37^{\circ} \mathrm{C}$, the sections were coated with rabbit anti-mouse type IV collagen (Biodesign, Kennebunkport, ME), rabbit anti-rat laminin (Chemicon International Inc., Temecula, CA), or rabbit anti-human tenascin (GIBCO BRL, Gaithersburg, MD) followed by biotin-conjugated goat antirabbit IgG (Tago Inc. Burlingame, CA), and streptavidin-conjugated FITC (Zymed Laboratories, Inc., San Francisco, CA). The sections were examined and coded, and the fluorescence intensity was graded on a $0-4+$ scale (24).

Light microscopic morphometry. Morphometric analyses were performed on plastic-embedded sections using a digitizing tablet and a video camera $(25,26)$. The mean glomerular volume was derived from the harmonic mean of the glomerular equatorial surface area (25). The surface area fraction of the cortex occupied by glomeruli was measured as previously described (26).

Glomerular cell number and turnover. The nuclei of 50 successively encountered glomerular profiles were counted by scanning hematoxylin/eosin-stained tissue sections in a serpentine fashion, and the relative glomerular cell number was calculated (27).

The labeling index was determined by measuring $\left[{ }^{3} \mathrm{H}\right]$ thymidine incorporation in glomeruli (27). The glomerular labeling index was determined by counting 50 successive glomeruli per section and expressed as the percentage of positively labeled cells (excluding Bowman's capsular cells) divided by the total glomerular cell number.

Electron microscopy. Electron microscopy was performed only in 3-mo-old mice (C57 +/+ and C57 Os/+). Four 1-2-mm thick transverse equatorial slices were cut with sharp single edge razor blades and placed in glutaraldehyde at $4^{\circ} \mathrm{C}$. After $1-3 \mathrm{~h}$, the kidney slices were further cut into radially oriented strips that were $\sim 1$-mm wide and extended from the capsule at one end to the inner stripe of the outer medulla at the other. The strips were stored overnight in the primary fixative at $4^{\circ} \mathrm{C}$. They were rinsed once in $0.1 \mathrm{M}$ Sorensen's phosphate buffer and twice in $0.1 \mathrm{M}$ sodium cacodylate buffer, $\mathrm{pH}$ 7.4, before fixation in a membrane-enhancing mixture of $1 \%$ osmium tetroxide and $0.8 \%$ potassium ferrocyanide buffered with $0.1 \mathrm{M}$ sodium cacodylate, $\mathrm{pH} \mathrm{7.4,} \mathrm{for} 2 \mathrm{~h}$ at $22^{\circ} \mathrm{C}$. The tissue strips were dehydrated in a graded ethanol series, then through propylene oxide to resin (Poly/Bed 812; Polysciences Inc., Warrington, PA), and polymerized in flat embedding molds at $60^{\circ} \mathrm{C}$ for $24 \mathrm{~h}$. The embedded strips were cut with a razor blade on a hot plate at $80^{\circ} \mathrm{C}$ into blocks of 2-4-mm length and glued to the surfaces of plastic stubs so that they could be sectioned longitudinally. Regions of the blocks containing several glomeruli were identified in semithin sections, and after retrimming, 90- $\mu \mathrm{m}$ sections were obtained on a Reichert-Jung Ultracut E ultramicrotome (Reichert, Vienna, Austria). The thin sections were mounted on high transmission 200 mesh copper grids and stained with uranyl acetate and lead citrate.

Electron microscopic morphometry. Sections were photographed on a Hitachi H-300 TEM (Hitachi Ltd., Tokyo, Japan), and the magnifications were calibrated. Four to six glomeruli were examined from each animal. They were selected randomly since all glomeruli in the sections were examined. One to five mesangial areas from each glomerulus were photographed as encountered at a magnification of either 4,000 or 7,000. Mesangial areas were digitized from the photomicrographs using a SummaSketch II digitizing pad in association with the digitizing component of the IBM PC-based Three-dimensional Reconstruction System (HVEM-3D) produced by the Laboratory for High Voltage Electron Microscopy at the University of Colorado, Boulder, CO. Using this digitizing program in conjunction with Microsoft Excel Version 5.0, the total mesangial cell area and the mesangial matrix area were determined for each micrograph, and the relative matrix area was expressed as a percentage of the total mesangial area.

Isolation of glomeruli and reverse transcription in situ. Glomeruli were isolated by microdissection and glomerular cDNA was obtained by in situ reverse transcription (21).

Competitive PCR. The primers for mouse $\alpha 1$ type IV collagen, laminin-B1, tenascin, 72-kD collagenase, and $\beta$-actin were previously described $(20,21,28)$. The corresponding PCR products were $484 \mathrm{bp}$ for $\alpha 1$ type IV collagen, 443 bp for laminin-B1, 460 bp for $\beta$-actin, 701 $\mathrm{bp}$ for $72-\mathrm{kD}$ collagenase, and $548 \mathrm{bp}$ for tenascin.

Competitive PCR assays were performed by adding decreasing amounts of mutant templates to glomerular cDNA (21). After PCR amplification, the ratio of mutant to glomerular cDNA band density was calculated by laser densitometry and plotted as a function of the amount of initial mutant template added to the reaction (21). The amount of glomerular cDNA was derived from linear regression analysis and expressed as mRNA levels. Duplicate or triplicate assays were performed $(21,28)$. Glomerular mRNA levels were corrected for glomerular cell number. The mean values obtained from mice were expressed as attomoles $\times 10^{-4}$ per glomerulus.

Table I. Comparison of Body, Heart, Kidney Weights, and Glomerular Size

\begin{tabular}{|c|c|c|c|c|c|c|}
\hline \multirow{2}{*}{$\begin{array}{l}\text { Age:: } \\
\text { Mice: }\end{array}$} & \multicolumn{2}{|c|}{3 months } & \multicolumn{2}{|c|}{5 months } & \multicolumn{2}{|c|}{5 months } \\
\hline & C57 +/+ & C57 OS/+ & C57 +/+ & C57 Os/+ & $\mathrm{ROP}+/+$ & ROP Os/+ \\
\hline $\mathrm{BW}(\mathrm{g})$ & $20.2 \pm 1.2$ & $20.7 \pm 2.7$ & $21.3 \pm 0.9$ & $22.9 \pm 1.6$ & $20.3 \pm 1.3$ & $22.3 \pm 1.4$ \\
\hline HW (mg) & $115 \pm 16$ & $122 \pm 15$ & $112 \pm 14$ & $117 \pm 13$ & $118 \pm 18$ & $122 \pm 3$ \\
\hline $\mathrm{KW}(\mathrm{mg})$ & $127 \pm 10$ & $86 \pm 11 *$ & $127 \pm 18$ & $84 \pm 3 *$ & $133 \pm 10$ & $104 \pm 13 *$ \\
\hline $\mathrm{GV}\left(\times 10^{5} \mu \mathrm{m}^{3}\right)$ & $2.0 \pm 0.3$ & $4.0 \pm 0.8^{*}$ & $2.2 \pm 0.3$ & $6.7 \pm 0.7 *$ & $2.5 \pm 0.3$ & $6.2 \pm 0.8 *$ \\
\hline
\end{tabular}

There were six mice in each group. ${ }^{*} P<0.01$, ROP OS/+ compared to ROP $+/+$ and $\mathrm{C} 57 \mathrm{Os} /+$ to $\mathrm{C} 57+/+$. BW, body weight; HW, heart weight; $\mathrm{KW}$, kidney weight; and GV, glomerular volume. 

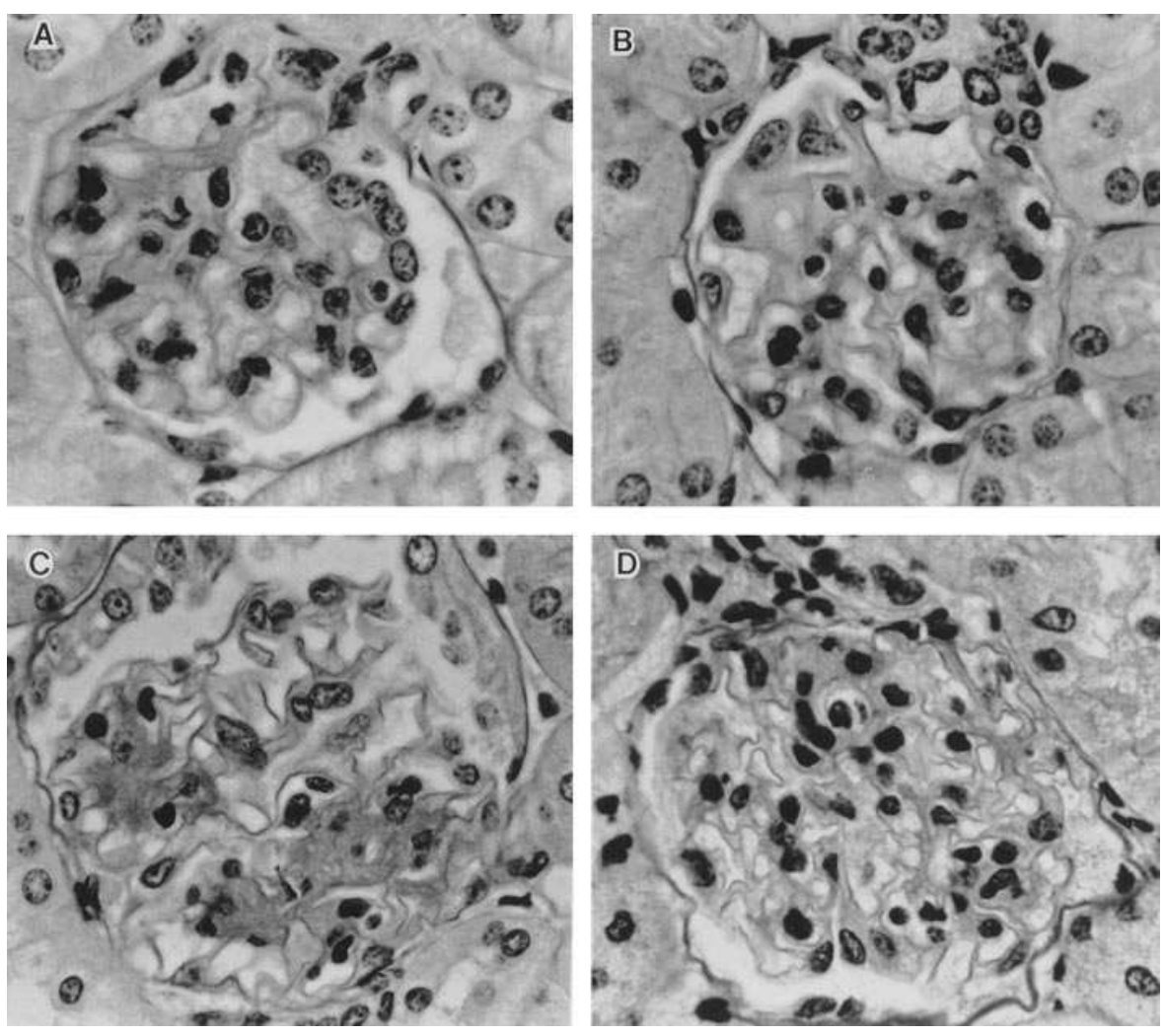

Figure 1. Light microscopy. Periodic acidSchiff methenamine-stained plastic-embedded sections, $\times 400$. $(A) \mathrm{ROP}+/+,(B)$ $\mathrm{C} 57+/+,(C) \mathrm{ROP}$ Os/ + , and $(D) \mathrm{C} 57$ Os/ + . All mice were 5 mo old.

Statistical analysis. All values were expressed as mean \pm SD. The two-tailed unpaired Student's $t$ test was used to evaluate differences between means for corresponding sets of data obtained from the Os/+ and $+/+$ mice. The level of significance $(P<0.05)$ was chosen a priori for all the analyses performed in the present study. The two-tailed unpaired Mann-Whitney nonparametric test was used to analyze differences in the immunofluorescence scores between the two groups as well as differences in mRNA levels between strains (ROP vs. C57).

\section{Results}

Kidney weight, glomerular volume and number. At 3 mo of age, C57 Os/+ mice had a 50\% reduction in mean glomerular number per kidney $(13,400 \pm 1,001$ vs. $6,420 \pm 600)(P<0.001)$, similar to that previously reported in ROP Os $/+$ mice $(14,340 \pm 1,020$ vs. $6,540 \pm 470)(P<0.001)(20)$. This was associated with a $34 \%$ reduction in kidney weight $(P<0.05)$ without a change in body or heart weight (Table I). Glomerular volume was increased twofold in C57 Os/ + mice at 3 mo $(P<$ $0.001)$, which did not differ from that found previously in ROP Os/+ (20). While the reduction in kidney weight remained at the same levels at 5 mo in C57 Os/+ mice, the mean glomerular volume was further increased (3.0-fold), a value not different from ROP Os/+ mice.

Histology. Although C57 Os/+ mice also had large glomeruli, there was no evidence of glomerulosclerosis at $3 \mathrm{mo}$, in contrast to what we previously found in ROP Os/+ mice (20). At $5 \mathrm{mo}$, the ROP Os/+ mice had severe and diffuse glomerulosclerosis that was restricted to the mesangial regions (Fig. 1 $C)$. In contrast, there was only a minimal increase in the amount of extracellular matrix in C57 Os/ + mice at 5 mo (Fig. $1 \mathrm{D})$. The increase in the mesangial areas was not associated with hypercellularity. However, in the most severely affected glomeruli the sclerosis resulted in a marked decrease in the size of the capillary lumens. Mesangial sclerosis, conspicuous in all glomeruli, varied somewhat in intensity between individual tufts but was evenly distributed between cortical and juxtamedullary glomeruli. There was no increase in the thickness of the peripheral glomerular basement membranes. Completely obsolescent glomeruli were not found. There were no tubulointerstitial or vascular lesions. Using a semiquantitative scoring method, mean mesangial sclerosis was $2.8 \pm 0.4$ in ROP $\mathrm{Os} /+$ and $1.2 \pm 0.5$ in $\mathrm{C} 57 \mathrm{Os} /+$ mice $(P<0.01)$. Interestingly, $\mathrm{ROP}+/+$ mice had a slightly increased amount of mesangial periodic acid-Schiff positive material, compared to $\mathrm{C} 57+1+$ mice ( $\mathrm{ROP}+/+: 0.5 \pm 0.5$ vs. $\mathrm{C} 57+/+$ : 0$)$. At 7.5 mo there were no histologic differences between $\mathrm{C} 57+/+$ and C57 Os/ + mice, although there was mild mesangial sclerosis in both (Fig. $2 A$ and $B$ ). The changes in $\mathrm{C} 57+/+$ or $\mathrm{C} 57 \mathrm{Os} /+$ mice at 7.5 mo were quite mild compared to ROP Os/+ mice at 5 mo of age (1.4 \pm 0.4 vs. $2.8 \pm 0.4)$.

Immunofluorescence microscopy. There was no accumulation of type IV collagen or laminin in C57 Os/+ mice at either 3 or 5 mo (Table II and Fig. $3 A$ and $B$ ). However, there was a modest increase in tenascin, consistent with the light microscopic findings of a minimal increase in the amount of mesangial matrix. (Fig. $3 \mathrm{C}$ ). Similar to what we previously reported in ROP Os/+ mice at $3 \mathrm{mo}$ (20), those at $5 \mathrm{mo}$ had a large excess of type IV collagen and of tenascin in the mesangial areas, which appeared consistent with the light microscopic lesions (Table II and Fig. $3 A$ and $C$ ). While there was no increase in the amount of laminin in ROP Os/+ mice compared with ROP +/+ mice, there was more laminin in ROP $+/+$ and ROP Os/ + mice than in either $\mathrm{C} 57+/+$ and $\mathrm{C} 57 \mathrm{Os} /+$ mice (Fig. $3 \mathrm{~B}$ ).

Electron microscopy. At 3 mo, there was a modest, but significant, increase in the total matrix area, as well as the per- 

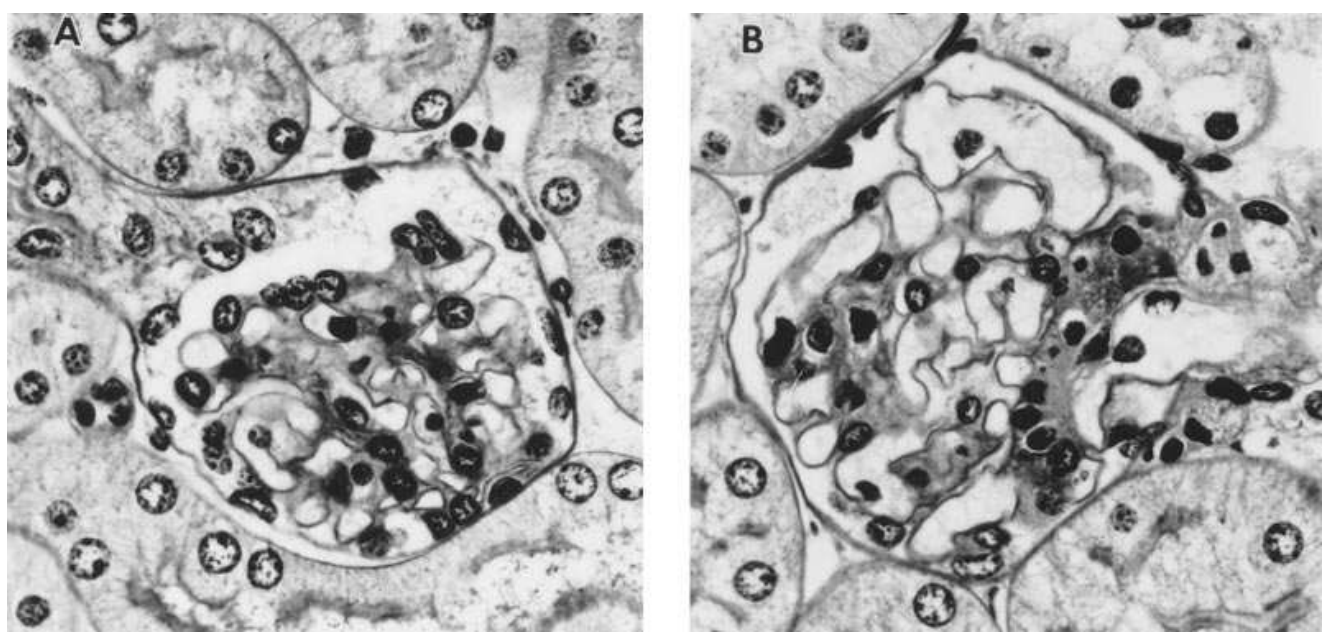

Figure 2. Light microscopy. Periodic acid-Schiff methenamine-stained plastic-embedded sections, $\times 400$. (A) C57 $+/+,(B) \mathrm{C} 57 \mathrm{Os} /+$. Mice were 7.5 mo old.

centage of mesangial matrix area in C57 Os/+ mice, compared to $\mathrm{C} 57+/+$ mice $(22.3 \pm 2.4 \%$ vs. $17.0 \pm 1.9 \%)(* P<0.05)$ (Fig. 4). However, this was considerably less than the 1.7 -fold increase previously noted between ROP Os/+ and ROP $+/+$ mice (20). The percentage of mesangial matrix area in C57 Os/+ mice was also much less than in ROP Os/+ mice $(22.3 \pm 2.4 \%$ vs. $38.7 \pm 6.6 \%)(20)$.

Urine protein/creatinine ratios. The ratios at $5 \mathrm{mo}$ of age did not differ among the four groups (ROP Os/+, 3.9 \pm 2.3 ; $\mathrm{ROP}+/+$ mice, 7.3 \pm 7.0 ; C57 Os/,$+ 6 / 2 \pm 4.1$; and $\mathrm{C} 57+/+$ mice, $3.7 \pm 1.0)$.

$m R N A$ levels. At 3 mo of age, glomerular $\alpha 1 \mathrm{IV}$ collagen mRNA levels were increased 1.4-fold in C57 Os/+, compared to $\mathrm{C} 57+/+$ mice (Table III, $P<0.05$ ). This increase was approximately half that previously found in ROP Os/+ mice at 3 mo (20). At 5 mo, ROP Os/+ mice had a 2.8-fold increase in a1IV collagen mRNA levels, whereas the levels in C57 Os/+ mice of the same age were 1.7-fold elevated (Table III, Fig. $5 A$ ).

The $72-\mathrm{kD}$ collagenase mRNA levels were 1.9 -fold increased $(P<0.05)$ in C57 Os/ + mice at 3 mo (Table III), a value similar to that reported previously in ROP Os/+ mice (1.7-fold). At 5 mo, C57 Os/+ and ROP Os/+ mice had 1.7and 1.5-fold increase, respectively (Table III, Fig. 5 B).

Table II. Quantitation of Glomerular Extracellular Matrix Accumulation by Immunofluorescence

\begin{tabular}{|c|c|c|c|c|c|c|}
\hline \multirow{2}{*}{$\begin{array}{l}\text { Age: } \\
\text { Mouse: }\end{array}$} & \multicolumn{2}{|c|}{3 months } & \multicolumn{2}{|c|}{5 months } & \multicolumn{2}{|c|}{5 months } \\
\hline & C57 +/+ & Ct7 Os/+ & C57 +/+ & C57 Os/+ & $\mathrm{ROP}+/+$ & ROP OS/+ \\
\hline ColIV & $1.0 \pm 0.6$ & $1.1 \pm 0.3$ & $1.0 \pm 0.3$ & $1.2 \pm 0.4$ & $1.0 \pm 0.3$ & $1.9 \pm 0.2^{* \ddagger}$ \\
\hline Laminin & $1.0 \pm 0.3$ & $1.3 \pm 0.4$ & $1.0 \pm 0.3$ & $1.1 \pm 0.4$ & $1.9 \pm 0.5^{\ddagger}$ & $2.8 \pm 0.4^{\ddagger}$ \\
\hline Tenascin & $1.0 \pm 0$ & $1.6 \pm 0.5^{*}$ & $1.0 \pm 0$ & $1.6 \pm 0.5^{*}$ & $1.0 \pm 0.5$ & $2.7 \pm 0.1^{* \neq}$ \\
\hline
\end{tabular}

Immunostaining for type IV collagen (ColIV), laminin, and tenascin was performed as described. 30 glomeruli per section and three sections per animal were scored as described. The means of scoring in six mice per group were shown. ${ }^{*} P>0.05$, when ROP OS/ + and C57 Os/ + mice were compared to ROP $+/+$ and $\mathrm{C} 57+/+$ mice, respectively; ${ }^{\ddagger} P<0.05$, when ROP $+/+$ and ROP Os/ + mice were compared to $\mathrm{C} 57+/+$ and C57 Os/+ mice, respectively.
At 3 mo, there were no significant differences in laminin B1 mRNA levels between C57 Os/ + and C57 $+/+$ mice (Table III), in keeping with results previously obtained in ROP Os/+ and ROP $+/+$ mice. Similarly, there were no differences between C57 Os/ + and C57 +/+ or ROP Os/ + and ROP $+/+$ mice at 5 mo (Table III, Fig. 5 C). However, the levels were significantly higher in ROP Os/+ and ROP $+/+$ mice, than in C57 Os/+ and C57 +/+ mice.

There was only a slight increase (1.4-fold) in tenascin mRNA levels in C57 Os/+ mice at 3 and 5 mo (Table III and Fig. 5 D). ROP Os/+ mice had a 1.7 -fold increase at $5 \mathrm{mo}$, similar to that previously observed at 3 mo (20).

$\beta$-actin mRNA levels did not differ among any of the groups, when adjusted for cell number (Table III).

Glomerular cell turnover. At $3 \mathrm{mo}$, there was an increase in both the mean cell number/glomerulus (21\%) and the glomerular labeling index (2.6-fold) in C57 Os/+ mice (Table IV), which was similar to that previously reported in ROP Os/+ mice (34\% and 2.4-fold) (20). At 5 mo, a similar increase in the mean cell number/glomerulus and in the glomerular labeling index was observed in both ROP Os/+ and C57 Os/+ mice, compared to controls (Table IV and Fig. $6 A, B, C$, and $D$ ). Thus, glomerular cell number and labeling index were increased in both ROP Os/+ and C57 Os/+ mice, and there was no significant difference between the values at 3 and 5 mo.

\section{Discussion}

The oligosyndactyly mouse (Os), a radiation-induced mutant model, has a $50 \%$ reduction in nephron number and enlarged glomeruli $(18,19)$. We reported that ROP Os/+ mice had glomerulosclerosis at 3 mo of age as defined by an increase in the amount of extracellular matrix in the mesangial regions (20). Thus, a congenital reduction in nephron number was associated with the development of severe glomerulosclerosis. To address the question of whether the amplitude of the response to nephron reduction might differ between strains, we compared ROP Os/+ and C57 Os/+ mice. We found that even though $\mathrm{C} 57 \mathrm{Os} /+$ mice had a 50\% reduction in renal mass and a twofold increase in glomerular size and glomerular cell labeling index, they developed only minimal evidence of glomerulosclerosis by light microscopy and electron microscopic mor- 
A

C57

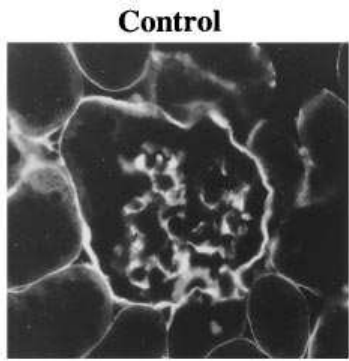

ROP

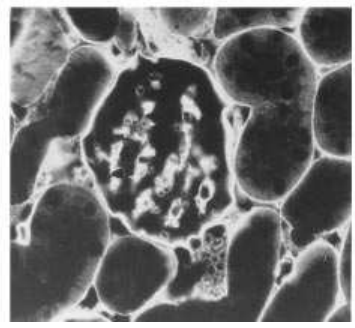

C

$$
\text { C57 }
$$

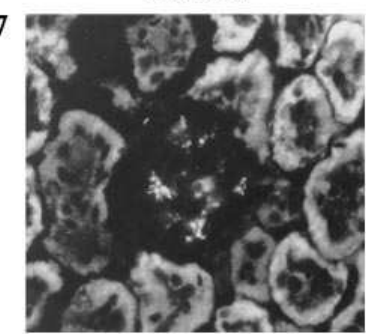

ROP

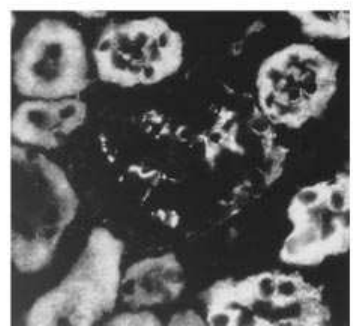

Os
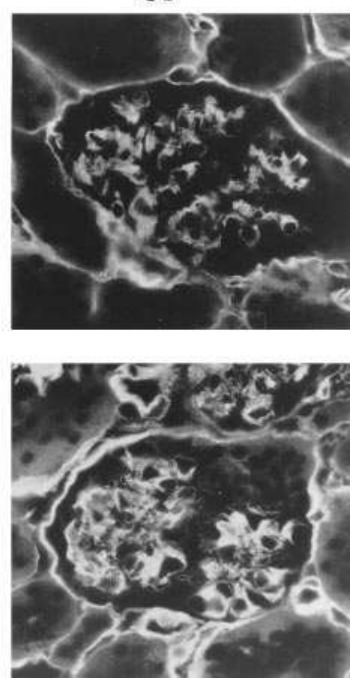

Os
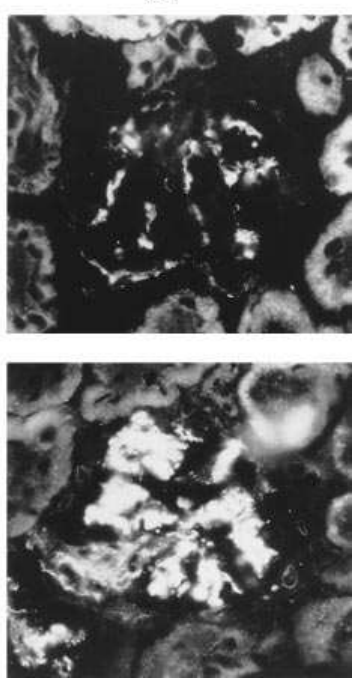

B C57

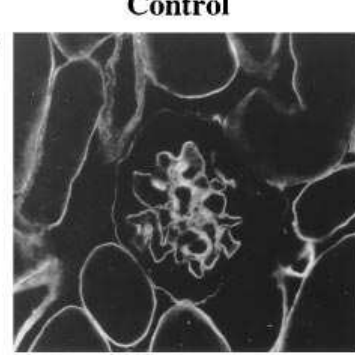

ROP

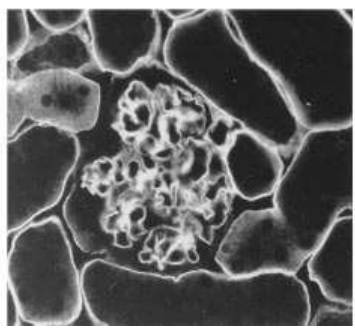

Os
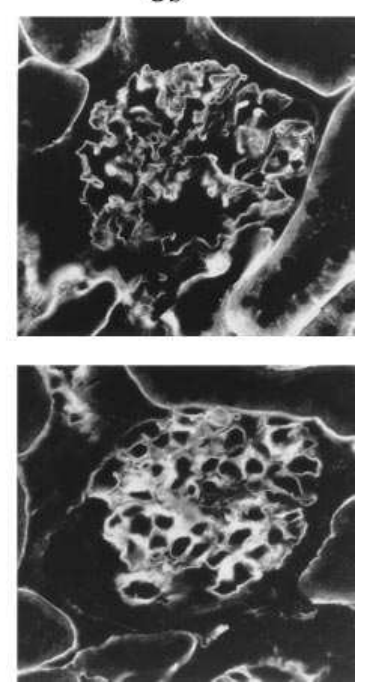

Figure 3. Immunofluorescence microscopy. Type IV collagen $(A)$, lami$\operatorname{nin}(B)$, and tenascin $(C), \times 400$.

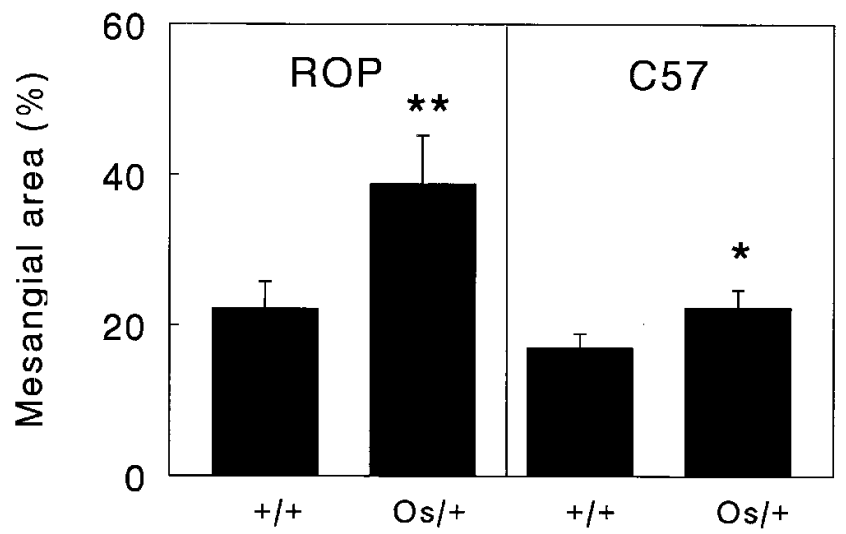

Figure 4. Electron microscopic morphometric analysis. Glomerular mesangial areas of 3-mo-old mice, expressed as percentage of total. $* P<0.05, * * P<0.005$. Data from ROP mice was previously published (20). 
Table III. Quantitation of Glomerular mRNA Levels by Competitive PCR

\begin{tabular}{|c|c|c|c|c|c|c|}
\hline \multirow{2}{*}{$\begin{array}{l}\text { Age: } \\
\text { Mice: }\end{array}$} & \multicolumn{2}{|c|}{3 months } & \multicolumn{2}{|c|}{5 months } & \multicolumn{2}{|c|}{5 months } \\
\hline & C57 +/+ & C57 Os/+ & C57 +/+ & C57 Os/+ & $\mathrm{ROP}+/+$ & ROP Os/+ \\
\hline$\alpha 1 \mathrm{IV}$ & $202 \pm 31$ & $274 \pm 53 *$ & $210 \pm 55$ & $365 \pm 72 *$ & $253 \pm 37$ & $708 \pm 55^{\ddagger}$ \\
\hline Lam B1 & $32 \pm 12$ & $47 \pm 17$ & $47 \pm 11$ & $65 \pm 13$ & $80 \pm 22^{\S}$ & $103 \pm 32^{\S}$ \\
\hline Tenascin & $358 \pm 101$ & $501 \pm 50 *$ & $430 \pm 115$ & $636 \pm 50^{*}$ & $534 \pm 88$ & $866 \pm 106^{*}$ \\
\hline 72 kD & $101 \pm 43$ & $192 \pm 51^{*}$ & $122 \pm 32$ & $210 \pm 56^{*}$ & $134 \pm 43$ & $193 \pm 40^{*}$ \\
\hline$\beta$-actin & $375 \pm 64$ & $421 \pm 115$ & $450 \pm 47$ & $512 \pm 180$ & $433 \pm 50$ & $500 \pm 55$ \\
\hline
\end{tabular}

Competitive PCR was performed in duplicate or triplicate. Means of six mice per group are shown. The absolute values were expressed as attmols $\times$ $10^{4} /$ glomeruli and were corrected for glomerular cell number. ${ }^{*} P<0.05,{ }^{\ddagger} P<0.005$, ROP Os/ + and C57 Os/ + mice compared to their respective controls; ${ }^{\S} P<0.05, \mathrm{ROP}+/+$ and ROP Os/+ mice compared to C57 +/+ and C57 Os/+ mice, respectively. $\alpha 1 \mathrm{IV}: \alpha 1$ type IV collagen; Lam B1: lami$\operatorname{nin}$ B1; $72 \mathrm{kD}$ : 72-kD collagenase.

type IV collagen in the glomerular mesangium. While the presence of the Os gene had no effect on the level of laminin expression in either the ROP or C57 strains, the baseline levels were significantly higher in ROP $+/+$ than in $\mathrm{C} 57+/+$ mice. (Table II and III). These data confirmed our previous observations in NOD mice that there are differences in the baseline levels of some ECM components between mouse strains (28). As shown previously, there were no significant differences in $\beta$-actin mRNA levels between Os and control mice when the data were corrected for cell number suggesting that the upregulation of gene expression in Os mice was selective, being largely restricted to type IV collagen. Since $\beta$-actin mRNA levels did not correlate with glomerular volume it appeared likely that glomerular cell hypertrophy was not a component of the increased glomerular volume in this model. Overall, our data suggested that the upregulation of ECM components depended largely on the genetic background of the mouse strain. The data in this study was derived entirely from studies in female mice although similar histologic lesions were present in males.

Studies in rats have suggested that there was a genetic basis for both the development and resistance to glomerulosclerosis (GS). Susceptibility to GS in rats has most often been reported in males. For instance, male rats in some Wistar strains spontaneously developed glomerulosclerosis, whereas females were resistant (30-33). The lesions, characteristic of those in rats, consisted of focal sclerosing GS. Initially manifest in a few rats at 4 mo, it affected all males by 7 mo. Kreisberg et al. described a similar lesion in the fawn-hooded rat (34). Simons et al., documented chronic renal failure with early systemic and glomerular hypertension, proteinuria and a high susceptibility to the development of focal GS (35). Another strain of Wistar rats, MWF/Ztm, was described by Remuzzi et al., in which the males develop focal GS (36). In the BUF/Mna rat, the spontaneous GS was reported to be determined by two autosomal recessive genes (37). In this model, both males and females are affected.

Several rat strains, including male PVG/c rats, were found to be completely resistant to the development of glomerulosclerosis after nephrectomy (38). The WKY male rat, which remained nonhypertensive after subtotal nephrectomy, did not develop GS. Similarly, BB rats had only minimal glomerular lesions after 5/6 renal ablation (39). Finally, ACI rats have been shown to be resistant to GS (37).

The time during development at which a reduction in neph- ron number is determined has been postulated to be an important factor in the postnatal development of glomerulosclerosis. For instance, a $20 \%$ nephron loss in utero, due to gentamicin toxicity or uterine arterial ligation in the mother, resulted in glomerulosclerosis in the offspring, whereas comparable nephron reduction in adult animals did not have adverse consequences $(11,12,40-42)$. The exact timing at which the reduction occurred was also shown to be critical in a series of experiments in metanephric cultures (43). The time at which the nephron reduction associated with expression of the Os+ gene has not been identified. However, this may not be a critical issue, since we found that C57 Os/+ mice, which have a similar reduction in nephron number, did not develop glomerulosclerosis. These data suggested that other genetic alterations could underlie the susceptibility to glomerular injury.

The relationship between cell proliferation and ECM synthesis in vivo has been studied extensively. In this study, we found that both ROP Os/+ and C57 Os/+ mice had a similar

\section{A}
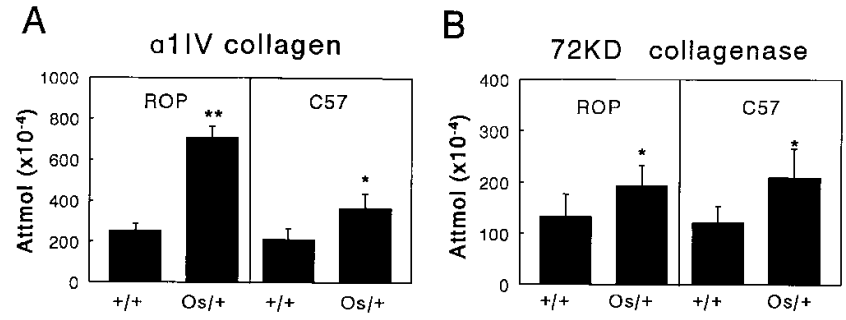

C
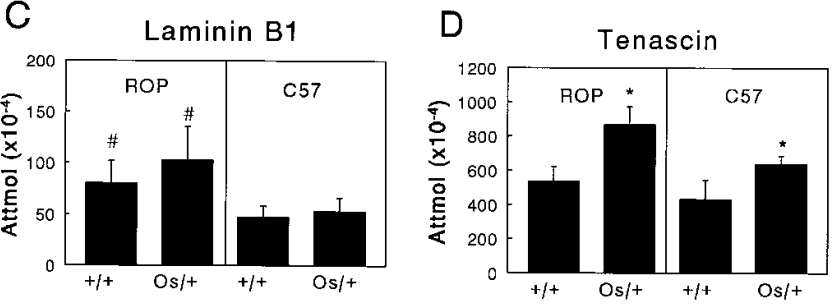

Figure 5. Glomerular mRNA levels at 5 mo of age. Levels were determine by competitive reverse transcription-PCR in microdissected glomeruli and corrected for cell number. $(A) \alpha 1$-IV collagen; (B) 72-kD collagenase; $(C)$ laminin $\mathrm{B} 1$; and $(D)$ tenascin. $* P<0.05$, $* * P<0.005, \mathrm{ROP}$ Os/ + and $\mathrm{C} 57 \mathrm{Os} /+$ mice compared to their respective controls; $+P<0.05, \mathrm{ROP}+/+$ and ROP Os/ + mice compared to $\mathrm{C} 57+/+$ and $\mathrm{C} 57 \mathrm{Os} /+$ mice, respectively. 


\begin{tabular}{|c|c|c|c|c|c|c|}
\hline \multirow{2}{*}{$\begin{array}{l}\text { Age: } \\
\text { Mice: }\end{array}$} & \multicolumn{2}{|c|}{3 months } & \multicolumn{2}{|c|}{5 months } & \multicolumn{2}{|c|}{5 months } \\
\hline & C57 +/+ & C57 Os/+ & $\mathrm{C} 57+/+$ & C57 Os/+ & $\mathrm{ROP}+/+$ & ROP Os/+ \\
\hline $\mathrm{GC}$ & $2,599 \pm 319$ & $3,139 \pm 400 *$ & $2,476 \pm 361$ & $3,124 \pm 156^{*}$ & $2,523 \pm 221$ & $3,356 \pm 254 *$ \\
\hline LI \% & $100 \pm 11$ & $262 \pm 73^{*}$ & $100 \pm 33$ & $246 \pm 25^{*}$ & $100 \pm 41$ & $283 \pm 26^{*}$ \\
\hline
\end{tabular}

Mean glomerular cell number (GC) and labeling index (LI) expressed as the ratio of Os mice to their respective controls (six mice per group). $* P<$ 0.001, ROP Os/+ and C57 Os/+ mice compared to their respective controls.

increase in both labeling index (2.4-fold) and cell number (1.3fold). Most of the labeled cells were in the centrolobular regions and were not macrophages by immunostaining (data not shown). The data provide strong evidence that glomerular cell turnover and ECM synthesis were not tightly linked in vivo, a finding consistent with our previous findings in vitro (44). The use of other models, in rats, has led to the conclusion that increased cell turnover rate and ECM synthesis were partially or closely correlated (45-47).

While the current data were consistent with previous observations that glomerular number correlated with glomerular volume $(9,48)$, they demonstrated that the increase in glomerular volume may be associated with, but was not sufficient for, the development of glomerulosclerosis. Observations in humans are also consistent with the postulate of a genetic compo- nent being critical in the genesis of glomerulosclerosis. Only a fraction of diabetic patients develop nephropathy, regardless of the level of glycemic control (1-3) and the slope of progression of a given glomerular disease varies between patients $(6$, $7)$. In addition, there are reports on the occurrence of focal segmental glomerulosclerosis in siblings and of a strong correlation with HLA- DR 4 and A28 antigens $(49,50)$.

Overall, our data support the observations that nephron reduction may result in the development of glomerulosclerosis, but they add the important proviso that the magnitude of the response and the ultimate outcome is largely dependent upon the genetic background. Further support of this postulate, in mice, comes from our previous observations that unilateral nephrectomy induced glomerular lesions in C57 mice transgenic for SV-40 Tag but not in nontransgenic controls (23).
A
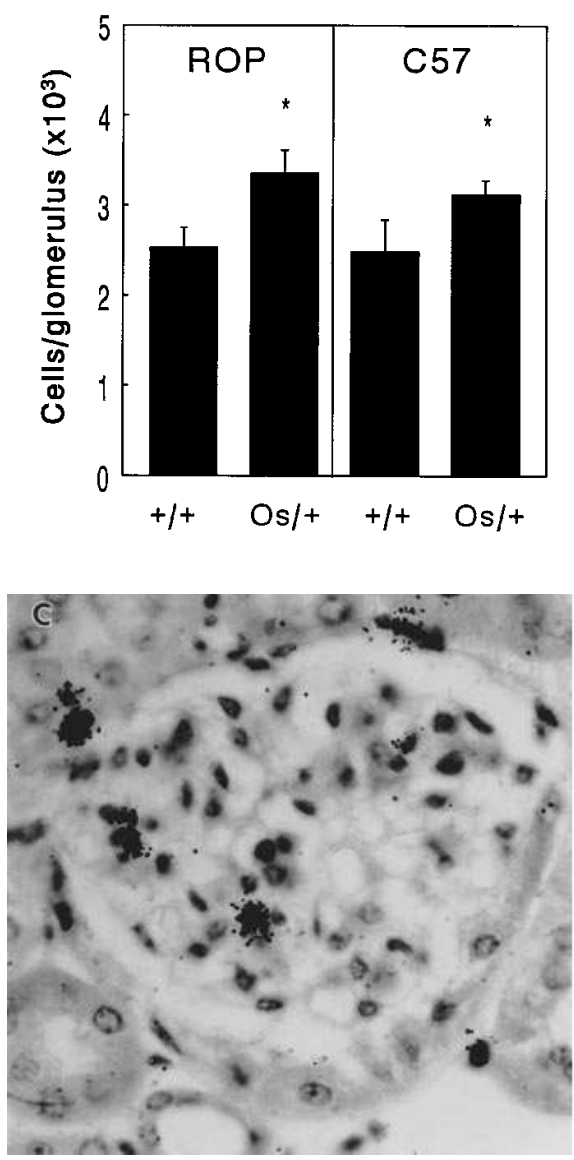

B
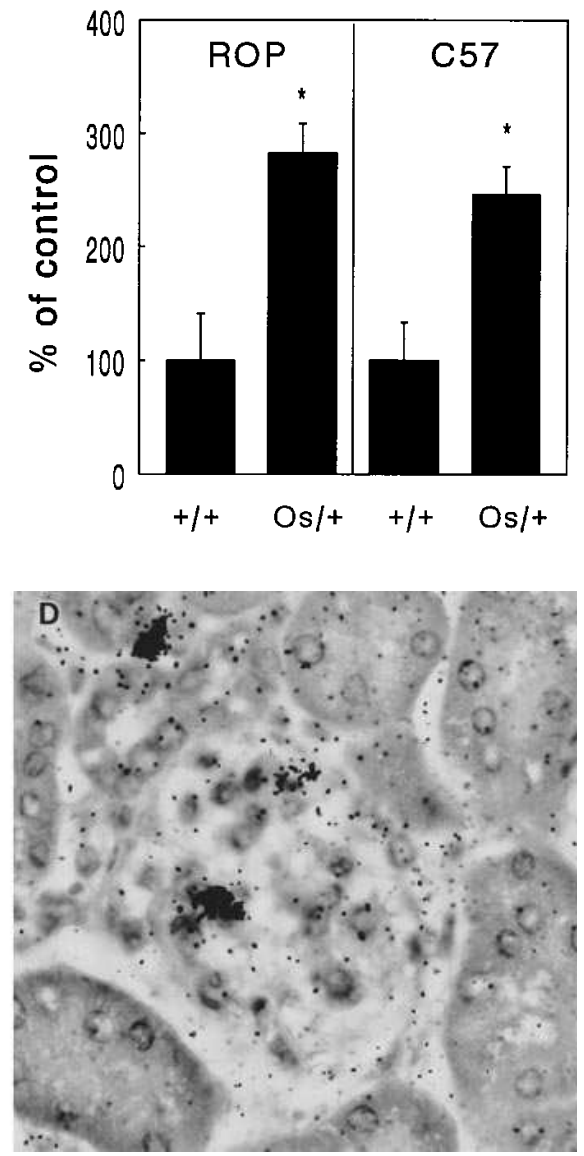

Figure 6. Glomerular cell turnover at 5 mo of age. $(A)$ Mean number of cells/glomerulus. $(B)\left[{ }^{3} \mathrm{H}\right]$ thymidine labeling index in glomerular tufts, expressed as percentage of control mice. ${ }^{*} P<0.001$, ROP Os/+ and $\mathrm{C} 57 \mathrm{Os} /+$ mice, compared to their respective controls. ( $C$ and $D$ ) Representative autoradiographs in ROP Os/ $+(C)$ and in $\mathrm{C} 57 \mathrm{Os} /+$ mice $(D)$. 


\section{Acknowledgments}

L.J. Striker is the recipient of an American Diabetes Association Mentor Award to C. Esposito. R.K. Zalups is supported by National Institutes of Health Grant ES-05157.

\section{References}

1. Borch-Johnsen, K., K. Norgaard, E. Hommel, E.R. Mathiesen, J.S. Jensen, T. Deckert, and H. Parving. 1992. Is diabetic nephropathy an inherited complication? Kidney Int. 41:719-722.

2. Krolewski, A.S., M. Canessa, J.H. Warram, L.M.B. Laffel, A.R. Christlieb, W.C. Knowler, and L.I. Rand. 1988. Predisposition to hypertension and susceptibility to renal disease in insulin-dependent diabetes mellitus. N. Engl. J. Med. 318:140-145.

3. Viberti, G.C. 1990. Mechanisms of diabetic renal and cardiovascular disease. Acta Diabetol. Lat. 27:267-276.

4. D'Amico, G. 1995. Immunoglobulin A nephropathy. In The Principles and Practice of Nephrology, 2nd ed. H.R. Jacobson, G.E. Striker, and S. Klahr, editors. MosbyYear Book, St. Louis, MO 133-139.

5. Julian, B.A., S.Y. Woodford, and R.W. Baehler. 1988. Familial Clustering and immunogenetic aspects of IgA nephropathy. Am. J. Kidney. Dis. 12: $366-370$.

6. Gilbert, R.E., C. Tsalamandris, L.A. Bach, S. Panagiotopoulos, R.C. O'Brien, T.J. Allen, I. Goodall, V. Young, E. Seeman, R.M.L. Murray, et al. 1993. Long-term glycemic control and the rate of progression of early diabetic kidney disease. Kidney Int. 44:855-859.

7. Jones, R.H., H. Hayakawa, J.D. Mackay, V. Parsons, and P.J. Watkins. 1979. Progression of diabetic nephropathy. Lancet. i:1105-1106.

8. Bhathena, D.B., B.A. Julian, R.G. McMorrow, and R.W. Baehler. 1985. Focal sclerosis of hypertrophied glomeruli in solitary functioning kidneys of humans. Am. J. Kid. Dis. 5:226-232.

9. Brenner, B.M. Nephron adaptation to renal injury or ablation. 1985. Am. J. Physiol. 249:F324-F337.

10. Kiprov, D.D., R.B. Colvin, and R.T. McCluskey. 1982. Focal and segmental glomerulosclerosis and proteinuria associated with unilateral renal agenesis. Lab. Invest. 46:275-281.

11. Gilbert, T., M. Lelievre-Pegorier, and C. Merlet-Benichou. 1991. Longterm effects of mild oligonephronia induced in utero by gentamicin in the rat. Pediatr. Res. 30:450-456.

12. Merlet-Benichou, C., B. Leroy, T. Gilbert, and M. Lelievre-Pegorier. 1993. Retard de croissance intra-uterin et deficit en nephrons. Medecine Sciences. 9:777-780.

13. Brenner, B.M., and G.M. Chertow. 1994. Congenital oligonephropathy and the etiology of adult hypertension and progressive renal injury. Am. J. Kid. Dis. 23:171-175.

14. Aperia, A., O. Broberger, and P. Wilton. 1978. Renal functional adaption in the remnant kidney in patients with agenesis and in patients nephrectomized in childhood. Acta Pediatr. Scand. 67:611-615.

15. Fetterman, G.H., and R. Habib. 1969. Congenital bilateral oligonephronic renal hypoplasia with hypertrophy of nephrons (Oligomeganephronia). Am. J. Clin. Path. 52:199-207.

16. Fogo, A., E.P. Hawkins, P.L. Berry, A.D. Glick, M.L. Chiang, R.C., MacDonell, Jr., and I. Ichikawa. 1990. Glomerular hypertrophy in minimal change disease predicts subsequent progression to focal glomerular sclerosis. Kidney Int. 38:115-123.

17. Pesce, C.M., K. Schmidt, A. Fogo, M.I. Okoye, R. Kim, L.J. Striker, and G.E. Striker. 1994. Glomerular size and the incidence of renal disease in African Americans and Caucasians. J. Nephrol. 7:355-359.

18. Stewart, A.D., and J. Stewart. 1969. Studies on syndrome of diabetes insipidus associated with oligosyndactyly in mice. Am. J. Pathol. 217:1191-1198.

19. Zalups, R.K. 1993. The Os/+ mouse: a genetic animal model of reduced renal mass. Am. J. Physiol. 264:F53-F60.

20. He, C.J., R.K. Zalups, D.A. Henderson, G.E. Striker, and L.J. Striker. 1995. Molecular analysis of spontaneous glomerulosclerosis in Os/+ mice, a model with reduced nephron mass. Am. J. Physiol. 269:F266-F273.

21. Peten, E.P., A. Garcia-Perez, Y. Terada, D. Woodrow, B.M. Martin, G.E. Striker, and L.J. Striker. 1992. Age-related changes in $\alpha 1-$ and $\alpha 2$-chain type IV collagen mRNAs in adult mouse glomeruli: competitive PCR. Am. J. Physiol. 263:F951-F957.

22. MacKay, K., L.J. Striker, C.A. Pinkert, R.L. Brinster, and G.E. Striker. 1987. Glomerulosclerosis and renal cysts in mice transgenic for the early region of SV 40. Kidney Int. 32:827-837.

23. MacKay, K., L.J. Striker, J.W. Stauffer, L.Y. Agodoa, and G.E. Striker. 1990. Relationship of glomerular hypertrophy and sclerosis: Studies in SV40 transgenic mice. Kidney Int. 37:741-748.

24. Yang, C.W., L.J. Striker, C. Pesce, W.Y. Chen, E.P. Peten, S. Elliot, T. Doi, J.J. Kopckick, and G.E. Striker. 1993. Glomerulosclerosis and body growth are mediated by different portions of bovine growth hormone: studies in transgenic mice. Lab. Invest. 68:62-70.

25. Doi, T., M. Hattori, L.Y.C. Agodoa, T. Sato, H. Yoshida, L.J. Striker, and G.E. Striker. 1990. Glomerular lesions in nonobese diabetic mouse: before and after the onset of hyperglycemia. Lab. Invest. 63:204-212.

26. Schmidt, K., C. Pesce, Q. Liu, R.G. Nelson, P.H. Bennett, H. Karnitschnig, L.J. Striker, and G.E. Striker. 1992. Large glomerular size in Pima Indians: lack of change with diabetic nephropathy. J. Am. Soc. Nephrol. 3:229235 .

27. Pesce, C.M., L.J. Striker, E.P. Peten, S.J. Elliot, and G.E. Striker. 1991. Glomerulosclerosis at both early and late stages is associated with increased cell turnover in mice transgenic for growth hormone. Lab. Invest. 65:601-605.

28. Yang, C.W., M. Hattori, H. Vlassara, C.J. He, M.A. Carome, E. Yamato, S. Elliot, G.E. Striker, and L.J. Striker. 1995. Overexpression of TGF- $\beta 1$ mRNA is associated with upregulation of glomerular tenascin and laminin gene expression in diabetic NOD mice. J. Am. Soc. Nephrol. 5:1610-1617.

29. Doi, T., L.J. Striker, K. Kimata, E.P. Peten, Y. Yamada, and G.E. Striker. 1991. Glomerulosclerosis in mice transgenic for growth hormone. Increased mesangial extracellular matrix is correlated with kidney mRNA levels. J. Exp. Med. 173:1287-1290.

30. Elema, J.D., and A. Arends. 1975. Focal and segmental glomerular hyalinosis and sclerosis in the rat. Lab. Invest. 33:554-561.

31. Bolton, W.K., F.R. Benton, J.G. Maclay, and B.C. Sturgill. 1976. Spontaneous glomerulosclerosis in aging Sprague-Dawley rats. Am. J. Pathol. 85: 277-302.

32. Couser, W.G., and M.M. Stilmant. 1975. Mesangial lesions and focal glomerular sclerosis in the aging rat. Lab. Invest. 33:491-501.

33. Striker, G.E., R.B. Nagle, P.W. Kohnen, and E.A. Smuckler. 1969. Response to unilateral nephrectomy in old rats. Am. Med. Assoc. Arch. Pathol. 87: 439-442.

34. Kreisberg, J.I., and M.J. Karnovsky. 1978. Focal segmental sclerosis in the fawn-hooded rat. Am. J. Pathol. 92:637-652.

35. Simons, J.L., A. P. Provoost, M.H. De Keijzer, S. Anderson, H.G. Rennke, and B.M. Brenner. 1993. Pathogenesis of glomerular injury in the Fawn-Hooded rat: effect of unilateral nephrectomy. J. Am. Soc. Nephrol. 4: 1362-1370.

36. Remuzzi, A., S. Puntorieri, C. Battaglia, T. Bertani, and G. Remuzzi. 1990. Angiotensin converting enzyme inhibition ameliorates glomerular filtration of macromolecules and water and lessens glomerular injury in the rat. $J$. Clin. Invest. 85:541-549.

37. Matsuyama, M., T. Ogiu, K. Kontani, C. Yamada, M. Kawai, H. Hiai, T. Nakamura, F. Shimuzu, T. Toyokawa, and Y. Kinoshita. 1990. Genetic regulation of the development of glomerular sclerotic lesions in the BUF/Mna rat. Nephron. 54:334-337.

38. Grond, J., J.Y. Beukers, M.S. Schilthuis, J.J. Weening, and J.D. Elema. 1986. Analysis of renal structural and functional features in two rat strains with a different susceptibility to glomerular sclerosis. Lab. Invest. 54:77-83.

39. Van Liew, J.B., C.W. Yang, L.J. Striker, and L.G. Feld. 1994. Resistance to glomerulosclerosis in biobreeding rats. J. Am. Soc. Nephrol. 5:973a. (Abstr.)

40. Argueso, L.R., M.L. Ritchey, E.T. Boyle, Jr., D.S. Milliner, E.J. Bergstralh, and S.A. Kramer. 1992. Prognosis of patients with unilateral renal agenesis. Pediatr. Nephrol. 6:412-416.

41. Baudoin, P., and A.P. Provoost. 1993. Effects of age at the time of unilateral nephrectomy and dietary protein on long-term renal function in rats. $P e$ diatr. Nephrol. 7:536-542.

42. Celsi, G., B. Jakobsson, and A. Aperia 1986. Influence of age on compensatory renal growth in rats. Pediatr. Res. 20:347-350.

43. Gilbert, T., S. Gaonach, E. Moreau, and C. Merlet-Benichou. 1994. Defect of nephrogenesis induced by gentamicin in rat metanephric organ culture. Lab. Invest. 70:656-666.

44. He, C.J., L.J. Striker, M. Tsokos, C.W. Yang, E.P. Peten, and G.E. Striker. 1995. Relationship between mesangial cell proliferation and types I and IV collagen mRNA levels in vitro. Am. J. Physiol. 269:C554-C562.

45. Alpers, C.E., K.L. Hudkins, A.M. Gown, and R.J. Johnson. 1992. Enhanced expression of "muscle specific" actin in glomerulonephritis. Kidney Int. 41:1134-1142.

46. Johnson, R.J., D. Lombardi, E. Eng, K. Gordon, C.E. Alpers, P. Pritzl, J. Floege, B. Young, J. Pippin, W.G. Couser, and G. Gabbiani. 1995. Modulation of experimental mesangial proliferative nephritis by interferon- $\gamma$. Kidney Int. 47:62-69.

47. Johnson, R.J., E.W. Raines, J. Floege, A. Yoshimura, P. Pritzl, C. Alpers, and R. Ross. 1992. Inhibition of mesangial cell proliferation and matrix expansion in glomerulonephritis in the rat by antibody to platelet-derived growth factor. J. Exp. Med. 175:1413-1416.

48. Provoost, A.P., P. Baudoin, M.H. De Keijzer, M. Van Aken, and J.C Molenaar. 1991. The role of nephron loss in the progression of renal failure: experimental evidence. Am. J. Kidney Dis. 17(Suppl.):27-32.

49. Glicklich, D., L. Haskell, D. Senitzer, and R.A. Weiss. 1988. Possible genetic predisposition to idiopathic focal segmental glomerulosclerosis. Am. J. Kidney Dis. 12:26-30.

50. McCurdy, F.A., P.J. Butera, and R. Wilson. 1987. The familial occurrence of the focal segmental glomerulosclerosis. Am. J. Kidney Dis. 10:467-469. 